Moira Marsh*

\title{
Select bibliography of Christie Davies' works
}

https://doi.org/10.1515/humor-2018-0150

\section{Introduction}

Before I began work on this list I was advised that Christie Davies was a prolific author, and truer words were never spoken. Christie was not only a leading scholar in international humor studies but also a sociologist, a frequent commentator on current affairs, and an even more prolific reviewer of books and art exhibitions. In addition to numerous academic books and articles, he published joke books $(1973,1978)$ and a children's book (2006). He wrote at least 101 book reviews between 1984 and 2018.

In the select bibliography that follows, I have attempted to include every academic book, article, and book review from Christie's pen, not just in humor studies but also in sociology. The range of scholarly journals in which he published is wide, including humor, sociology, folklore, anthropology, religious studies, and death studies. He published in venues worldwide from Poland to Japan and Australia. He also wrote for important magazines such as the Economist and the New Criterion. In addition, he published an enormous amount in online journals and blogs. For the Social Affairs Unit blog alone, he wrote 152 posts from July 2004 through April 2013, making him the single most prolific contributor to this libertarian site. Space and time preclude a complete listing of all of the blog posts and art exhibit reviews. I have included all that pertain to humor along with a select few items on other topics to give a sense of the full range of Christie's thought.

Regardless of the venue, Christie writes clearly, precisely, and with a wicked sense of humor. I believe that this clear prose stems from the fact that he was never afraid to say exactly what he thought. He did not hold with obfuscation or political correctness and had no patience with those who did. His sociological training shows up in a recurring emphasis on the superiority of data over ideology. "We need to ask the questions how? how much? and why?" he wrote, in "Goffman's concept of the total institution" (1989), an injunction that he repeated in other writings. He appreciated

*Corresponding author: Moira Marsh, Indiana University, 1320 E 10th St., Bloomington, USA, E-mail: molsmith@indiana.edu 
good humor and was a master humorist himself, but he did not allow his love for a good joke to influence his thought about the potential power of humor.

I leave off with a tantalizing glimpse of what might have been. "Well," he wrote at the conclusion of a 2005 blog post about the pleasures of retirement,

I must get back to writing my next book, which is to be called Bastards! It is not about New Labour but is a comparative and historical study of illegitimacy. I have thirty years of reading, thinking and note taking to catch up on and I no longer have to go to the office" (“On Retirement," 2005).

Sadly, we will have to imagine that book. It would have been a great one.

\section{1}

The incentive case. The case for reducing direct personal taxation. London: Conservative Political Centre.

\section{2}

With David Rhys Davies. Incentive to invest. London: Conservative Political Centre.

\section{3}

With Russell Lewis. The reactionary joke book. London: Wolfe.

With Ruth Brandon. Wrongful imprisonment: mistaken convictions and their consequences. London: Allen and Unwin.

\section{5}

Permissive Britain: social change in the sixties and seventies. London: Pitman. 


\section{7}

The changing stereotype of the Welsh in English jokes. In Antony J. Chapman, Hugh C. Foot \& B. M. Foss (eds.), It's a funny thing, humour, 311-314. Oxford: Pergamon.

\section{8}

With Rajeev Dhavan (eds.). Censorship and obscenity. London: M. Robertson. [Also published Totowa, N.J.: Rowman and Littlefield].

With Rajeev Dhavan. How our rulers argue about censorship. In Rajeev Dhavan \& Christie Davies (eds.), Censorship and obscenity, 9-36. Totowa, NJ: Rowman \& Littlefield.

Welsh jokes. Cardiff: Jones.

\section{9}

The social origins of some sexual taboos. In Mark Cook \& Glenn Wilson (eds.), Love and attraction: An international conference, 381-386. Oxford: Pergamon Press.

\section{1}

Review of John Boswell, Christianity, social tolerance and homosexuality: Gay people in Western Europe from the beginning of the Christian era to the fourteenth century. New Society 55(952). 298-299.

\section{2}

Ethnic jokes, moral values and social boundaries. British Journal of Sociology 33 (3). 383-401.

Italian military efficiency: A debate: Itali sunt imbelles. Journal of Strategic Studies 5(2). 266-269. DOI: https://doi.org/10.1080/01402398208437114.

Sexual taboos and social boundaries. American Journal of Sociology 87(5). 1032-1063. DOI: https://doi.org/10.1086/227554. 


\section{3}

Crime, bureaucracy, and equality. Policy Review 23. 89-105.

Review of Bernice Martin, A sociology of contemporary cultural change. Reviewing Sociology 2(5). 7-10.

Review of Norbert Elias, The civilising process. Vol. 2: State formation and civilisation. Reviewing Sociology 2(5). 7-10.

\section{4}

Commentary on Anton C. Zijderveld's Trend report on 'The sociology of humor and laughter'. Current Sociology/La Sociologie Contemporaine 32(1). 142-157. DOI: https://doi.org/10.1177/001139284032001010.

Review of Fox Butterfield, China, Alive in the bitter Sea. Reviewing Sociology 3(3). 47-48.

Review of Jack Goody, Cooking, cuisine and class: A Study in Comparative Sociology. Reviewing Sociology 3(2). 15-17.

Review of Robert Skidelsky, John Maynard Keynes, Vol. I: Hopes betrayed 1883-1920. Reviewing Sociology 3(3). 23-25.

\section{5}

Ethnic jokes and social change: The case of the Welsh. Immigrants \& Minorities 4 (1). 46-63. DOI: https://doi.org/10.1080/02619288.1985.9974596.

[as Christie J. C. H. Davies]. Review of Eileen Barker, The making of a Moonie: Choice or brainwashing? British Journal of Criminology 25(4). 419-420.

\section{6}

[as Christie J. C. H. Davies] with Eugene Trivizas. Tactics of legal reform: Learning from the recent past. Howard Journal of Criminal Justice 25(1). 25-32. DOI: https://doi.org/10.1111/j.1468-2311.1986.tb00542.x. 


\section{7}

Language, identity and ethnic jokes about stupidity. International Journal of the Sociology of Language 65. 39-52.

\section{8}

Apartheid versus capitalism: The South African contradiction. Reading: University of Reading, Graduate School of European and International Studies.

Laughter, jokes and puns: The sociology of humour [Review essay]. Reviewing Sociology (New Series) 5(3). 3-8.

Stupidity and rationality: Jokes from the iron cage. In Chris Powell \& George E. C. Paton (eds.), Humour in society: Resistance and control, 1-32. London: Palgrave Macmillan UK.

\section{9}

1988 - Britain's year of the Dutch. New European 1(4). 11-12.

Goffman's concept of the total institution: Criticisms and revisions. Human Studies 12(1). 77-95. DOI: https://doi.org/10.1007/bf00142840.

Review of Marvin R. Koller, Humor and society: Explorations in the sociology of humor. Humor 2(3). 299-301.

Solving the Rumanian problem. National Review 41(25). 37.

Time to talk Turkey. New European 2(2). 22-24.

\section{0}

The Anglo-Saxon revolutions. International Social Science Review 65(4). 147-153. The collapse of the world's best political jokes. National Review 42(15). 32.

The Empire writes back [Review article]. Reviewing Sociology (New Series) 7 (1). 8-23.

Ethnic humor around the world: a comparative analysis. Bloomington: Indiana University Press.

An explanation of Jewish jokes about Jewish women. Humor 3(4). 363-378. DOI: https://doi.org/10.1515/humr.1990.3.4.363. 
From the sacred hierarchies to flatland: a sociological account of moral, social and legal changes in twentieth century Britain, with particular reference to capital punishment, homosexuality and abortion. Canterbury: Centre for the Study of Religion and Society. University of Kent.

Jokes and the dismal science. Economic Affairs 11(1). 30-42. DOI: https://doi. org/10.1111/j.1468-0270.1990.tb00754.x.

Making fun of work: Humor as sociology in the works of H. G. Wells. In Patrick Parrinder \& Christopher Rolfe (eds.), H. G. Wells under revision: Proceedings of the International H. G. Wells Symposium London, July 1986., 82-96. Selinsgrove, PA; London: Susquehanna UP; Associated UP.

A new solution for Europe's regional problems. New European 3(2-3). 52-54.

Paying one's debts. National Review 42(24). 43-44.

Review of Marvin R. Koller, Humor and society: Explorations in the sociology of humor. Reviewing Sociology (New Series) 7(1). 28-31.

Review of On humour, its nature and its place in modern society. Humor 3 (2). 217-219.

\section{1}

Concentric overlapping and competing loyalties and identities: The implication for education. International Journal on the Unity of the Sciences 4(4). 435-463.

Ethnic humor, hostility, and aggression: a reply to Elliott Oring. Humor 4 (3-4). 415. DOI: https://doi.org/10.1515/humr.1991.4.3-4.415.

European time, cows and Scotsmen. Economic Affairs 11(5). 25-26. DOI: https://doi.org/10.1111/j.1468-0270.1991.tb00814.x.

Exploring the thesis of the self-deprecating Jewish sense of humor. Humor 4 (2). 189-209.

Fooltowns: traditional and modern, local, regional and ethnic jokes about stupidity. In Gillian Bennett (ed.), Spoken in jest, 215-235. Sheffield, Eng.: Sheffield Academic Press.

Nationalisms, education and the individual. Reading: University of Reading, Graduate School of European and International Studies.

The Need for ecological cooperation in Europe. International Journal on the Unity of the Sciences 4(2). 201-216.

Safely executed. National Review 43(14). 44-45.

A socialist answer to drugs. Economic Affairs 11(2). 17-18. DOI: https://doi. org/10.1111/j.1468-0270.1991.tb00765.x. 
Very common currencies. Economic Affairs 11(3). 25-26. DOI: https://doi.org/ 10.1111/j.1468-0270.1991.tb00784.x.

\section{2}

2042: A choice of futures - A view from outside America. International Social Science Review 67(4). 147-158. https://www.jstor.org/stable/41882072.

A capital idea. Economic Affairs 12(3). 26-27. DOI: https://doi.org/10.1111/j. 1468-0270.1992.tb00861.x.

From Gabrovo to Scotland and Ceredigion and from the Sopi to the Irish: A comparison of Bulgarian and British humour. In Elizabeth I. Kwasnik (ed.), British and Bulgarian ethnography, 71-76. Liverpool: Nat. Museums \& Galleries on Merseyside.

How nations fall apart. New European 5(4). 22-24.

Issues of life and death: a comparative international study of capital punishment and the law relating to abortion. Reading: University of Reading.

The Protestant ethic and the comic spirit of capitalism. The British Journal of Sociology 43. 421-442. DOI: https://doi.org/10.2307/591543.

Review of Annette Lawson, Adultery: An analysis of love and betrayal Reviewing Sociology (New Series) 8(2). 65-67.

Review of Basil Don [pseud.], The very best of Essex girl jokes. Humor 5(4). 435.

Review of Gloria Kaufman and Debra Jacobs, In stitches - a patchwork of feminist humor and satire. Humor 5(4). 425.

Review of Stanislav Andreski, Syphilis, Puritanism and witch-hunts. Reviewing Sociology (New Series) 8(2). 78-81.

With Knud P. Pedersen, Sylvia Chittenden de Condylis \& Jonathan Rickford. Symposium on the values of small states. New European 5(4). 16-31.

\section{3}

Do we really need a coal industry? Economic Affairs 13(2). 49. DOI: https://doi. org/10.1111/j.1468-0270.1993.tb00044.x.

Exploring the thesis of the self-deprecating Jewish sense of humor. In Avner Ziv \& Anat Zajdman (eds.), Semites and stereotypes: Characteristics of Jewish humor, 29-46. Westport, CT: Greenwood. 
Review of Bryan R. Wilson, The social dimensions of sectarianism, sects and new religious movements in contemporary society. Reviewing Sociology (New Series) 8(3). 27-33.

Review of David Cohen, Law, sexuality, and society: The enforcement of morals in classical Athens. American Journal of Sociology 98(4). 992-993. DOI: https://doi.org/10.1086/230133.

Review of Plinio Prioreschi, A history of human responses to death, mythologies, rituals and ethics. Reviewing Sociology (New Series) 8(3). 33-37.

Review of Ralph Houlbrooke [ed], Death, ritual and bereavement. Reviewing Sociology (New Series) 8(3). 33-37.

Review of Tim Newburn, Permission and regulation, law and morals in postwar Britain. British Journal of Criminology 33(4). 572. https://www.jstor.org/ stable/23637641.

Trial by judges. National Review 45(10). 46-48.

\section{4}

A response to a response to my response to In stitches. Humor 7(1). 74-83.

\section{5}

Review of J. A. Barnes, A Pack of lies: Towards a sociology of lying. American Journal of Sociology 101(1). 260-262. DOI: https://doi.org/10.1086/230724.

Review of William A. Coupe, German political satires from the Reformation to the Second World War: Part I, 1500-1848. Humor 8(4). 429-431.

What made them moral? National Review 47(6). 63-64.

\section{6}

The British state and the power of life and death. In R. C. Whiting \& S. J. D. Green (eds.), The boundaries of the state in modern Britain, 341-374. Cambridge: Cambridge University Press.

Dirt, death, decay and dissolution: American denial and British avoidance. In Glennys Howarth \& Peter C. Jupp (eds.), Contemporary issues in the sociology of death, dying and disposal, 60-71. London: Palgrave Macmillan UK. 
Ethnic humor around the world: a comparative analysis. Paperback edn Bloomington: Indiana University Press.

Review of Elliott Oring, Jokes and their relations. Reviewing Sociology (New Series) 9(3). 75-77. http://www.reading.ac.uk/RevSoc/archive/volume9/num ber3/9-3x.htm.

Review of P.A.J. Waddington, The strong arm of the law, Armed and public order policing. Reviewing Sociology (New Series) 9(1). 37-39. http://www.read ing.ac.uk/RevSoc/archive/volume9/number1/9-1q.htm.

Review of Richard Lynn, The secret of the miracle economy: different national attitudes to competitiveness and money. Reviewing Sociology (New Series) 9(1). http://www.reading.ac.uk/RevSoc/archive/volume9/number1/9-11. htm.

Review of Stanislav Andreski, Wars, revolution, dictatorships: Studies of historical and contemporary problems from a comparative viewpoint and Uta Gerhardt (ed), Talcott Parsons on National Socialism. Reviewing Sociology (New Series) 9(2). 51-54. http://www.reading.ac.uk/RevSoc/archive/volume9/num ber2/9-2r.htm.

The violent bear it away. National Review 48(21). 52-54.

\section{7}

The last gasps of a dead tongue. Times Higher Education Supplement (1287). 16.

The Newfoundland joke: A Canadian phenomenon viewed in a comparative international perspective. Humor 10(2). 137-164. DOI: https://doi.org/10.1515/ humr.1997.10.2.137.

The progress of Australian humour in Britain. In R Matte \& Jessica Milner Davis (eds.), Readings from the International Conference on Humour, 15-32. Sydney: University of New South Wales Press.

Review of C Ronald Huff, Arye Rattner, and Edward Sagarin, Convicted but innocent: Wrongful convictions and public policy. Reviewing Sociology (New Series) 10(3). http://www.reading.ac.uk/RevSoc/archive/volume10/number3/103s.htm.

Review of Colin Pritchard, Suicide: The ultimate rejection. Reviewing Sociology (New Series) 10(3). http://www.reading.ac.uk/RevSoc/archive/ volume10/number3/10-3h.htm.

Review of Kathleen Stokker, Folklore fights the Nazis: humor in occupied Norway 1940-1945. Humor 10(3). 349-352. 
Review of Nils Retterstøl, Suicide: A European perspective. Reviewing Sociology (New Series) 10(1). http://www.reading.ac.uk/RevSoc/archive/ volume10/number1/10-1z.htm.

Review of Peter Cook, The industrial craftsworker: Skill, managerial strategies and workplace relationships. Sociology: The Journal of the British Sociological Association 31(1). 186-187. DOI: https://doi.org/10.1177/ 0038038597031001029.

Review of Richard F. Hamilton, The social misconstruction of reality, Validity and verification in the scholarly community. Sociology: The Journal of the British Sociological Association 31(4). 816-817. DOI: https://doi.org/10.1177/ 0038038597031004018.

\section{8}

With Mark Neal. The corporation under siege: Exposing the devices used by activists and regulators in the non-risk society. London: Social Affairs Unit.

The dog that didn't bark in the night: A new sociological approach to the cross-cultural study of humor. In Willibald Ruch (ed.), The sense of humor: Explorations of a personality characteristic, 293-306. Berlin, Boston: De Gruyter.

Jewish identity and survival in contemporary society: The evidence from Jewish humor. In E. Krausz \& G. Tulea (eds.), Jewish survival: The identity problem at the end of the twentieth century, 123-144. Piscataway: Transaction Publishers.

Jewish jokes, anti-Semitic jokes and Hebredonian jokes. In Avner Ziv (ed.), Jewish humor, 75-96. London and New Brunswick, NJ: Transaction Publishers.

Jokes and their relation to society. New York: Mouton de Gruyter.

Review of Jan Bremmer and Herman Roodenburg, A cultural history of humour. From antiquity to the present day. The British Journal of Sociology 49 (2). 325-326. DOI: https://doi.org/10.2307/591322.

Review of Jan Bremmer and Herman Roodenburg, A cultural history of humour. From antiquity to the present day. American Anthropologist 100(1). 241-242. DOI: https://doi.org/10.1525/aa.1998.100.1.241.

Review of Peter L. Berger, Redeeming laughter, the comic dimension of human experience. British Journal of Sociology 49(4). 670-671. DOI: https://doi. org/10.2307/591295.

Review of Steven Wagg, ed., Because I tell a joke or two, Comedy, politics and social difference. The Sociological Review 46(4). 875-877. DOI: https://doi. org/10.1111/1467-954X.00144. 


\section{9}

Change and continuity in one of Europe's oldest comic ethnic scripts. Humor 12 (1). 1-31.

With Eugene Trivizas \& Roy Wolfe.The failure of calendar reform (1922-1931): Religious minorities, businessmen, scientists, and bureaucrats. Journal of Historical Sociology 12(3). 251-270. DOI: https://doi.org/10.1111/1467-6443.00091.

The fragmentation of the religious tradition of the creation, after-life and morality: Modernity not post-modernity. Journal of Contemporary Religion 14(3). 339-360. DOI: https://doi.org/10.1080/13537909908580874.

Jokes on the death of Diana. In Tony Walter (ed.), The mourning for Diana, 253-268. Oxford: Berg.

Review of P. K. Devine, Devine's folklore of Newfoundland in old words, phrases, and expression. Humor 12(1). 95-96.

\section{0}

Cutting edge. Times Higher Education Supplement (1450). 28.

With Mark Neal. Durkheim' s altruistic and fantastic suicide. In W. S. F. Pickering \& Geoffrey Walford (eds.), Durkheim's Suicide: A century of research and debate, 36-52. London: Routledge.

Questions of power and theory: A reply to Salvatore Attardo. Humor 13(4). 469-472. DOI: https://doi.org/10.1515/humr.2000.13.4.469.

Review of Emil A. Draitser, Taking penguins to the movies, ethnic humor in Russia. Humor 13(4). 477-481.

Review of Robert A. Hinde, Why gods persist: a scientific approach to religion. Journal of Contemporary Religion 15(2). 286-288.

Reviews of Alan Dundes, Holy writ as oral lit: The Bible as folklore; Alan Dundes, From game to war; and Alan Dundes, Two tales of crow and sparrow. Journal of Contemporary Religion 15(3). 435-438. DOI: https://doi.org/10.1080/ 713676043.

The savage style of Jaroslav Hašek: "The good soldier Švejk" as a politically incorrect comic masterpiece. Stylistyka (Opole). 9. 301-313.

With Mark Neal, John Varty, Geoffrey Walford, Robert Alun Jones \& William Ramp. Teaching Durkheim's Suicide: A symposium. In W. S. F. Pickering \& Geoffrey Walford (eds.), Durkheim's Suicide: A century of research and debate, 180-200. London: Routledge. 


\section{1}

The humorous use of the contrast between standard educated English and local dialect in Scottish jokes. Stylistyka (Opole) 10. 111-123.

Humour is not a strategy in war. Journal of European Studies 31(123). 395-412. DOI: https://doi.org/10.1177/004724410103112309.

Place, time, and family in Mormonism. Dialogue (Stanford, Calif.) 34(3). 9-18.

Review of Alan Dundes ed., International folkloristics, classic contributions by the founders of folklore. Folklore 112(1). 114-116. DOI: https://doi.org/10. 1080/00155870120037984.

Review of Alan Dundes, Two tales of crow and sparrow. Humor 14(3). 303-305.

Stigma, uncertain identity and skill in disguise. In Efrat Tseëlon (ed.), Masquerade and identities: Essays on gender, sexuality and marginality, 38-53. London, England: Routledge.

\section{2}

With Eugene Trivizas. The collapse of the moral boundaries of peripheral countries. In G. Preyer \& M. Bös (eds.), Borderlines in a globalized world: New perspectives in a sociology of the world-system, 175-188. Dordrecht: Springer Netherlands.

The mirth of nations. New Brunswick, NJ: Transaction Publishers.

Review of Alan Dundes and Carl R. Pagter, Why don't sheep shrink when it rains: A further collection of photocopier folklore. Folklore 113(1). 122-124. https://www.jstor.org/stable/1261025.

Review of Alphons Silbermann and Ladislaus Lob, Grovelling and other vices: The sociology of sycophancy. Folklore 113(1). 124. https://www.jstor.org/ stable/1261026.

Review of Robert L. Latta, The basic humor process: A cognitive-shift theory and the case against incongruity. Journal of the Royal Anthropological Institute 8 (3). 610-611. http://www.jstor.org/stable/3134583.

Review of Salvatore Attardo, Humorous texts: a semantic and pragmatic analysis. Humor 15(4). 448-451.

Reviews of Les mots du rire: comment les traduire? Essais de lexicologie contrastive./Traduire l'humour/humour, culture, traduction(s). The Translator 8(2). 417-421. DOI: https://doi.org/10.1080/13556509.2002.10799141. 


\section{3}

The Elgin Marbles are going to Tennessee. The Social Affairs Unit. http://www. socialaffairsunit.org.uk/blog/archives/000145.php.

With Gō Abe. Esunikku jōku: Jiko o warai tasha o warau. Kodansha.

A Greek bearing gifts: the literary talents of Eugene Trivizas. Bookbird: The Journal of IBBY, the International Board on Books for Young People 41(3). 23-35.

IQ and the wealth of nations. Economic Affairs 23(2). 60-61.

Jokes that follow mass-mediated disasters in a global electronic age. In Peter Narvaez (ed.), Of corpse: Death and humor in folklore and popular culture, 15-34. Logan, Utah: Utah State University Press.

Marketing the revolution, the new anti-capitalism and the attack upon corporate brands. Economic Affairs 23(3). 61-62.

Review of Anna T. Litovkina, A proverb a day keeps boredom away. Folklore 114(1). 141-142. https://www.jstor.org/stable/30035091.

Review of David Martin, Christian language and its permutations: Essays in sociological understanding. Journal of Contemporary Religion 18(3). 411-412. DOI: https://doi.org/10.1080/13537900310001601730.

Review of G. Gordon Betts. The twilight of Britain: Cultural nationalism, multiculturalism, and the politics of toleration. Albion 35(3). 551-552. DOI: https://doi.org/10.2307/4054128.

\section{4}

Censored postcards of Donald McGill. The Social Affairs Unit. http://www. socialaffairsunit.org.uk/blog/archives/000130.php.

Creationism in schools: a small price for a big reward. The Social Affairs Unit. http://www.socialaffairsunit.org.uk/blog/archives/000158.php.

Grin and Blair It - Cartoons of Tony Blair. The Social Affairs Unit. http://www. socialaffairsunit.org.uk/blog/archives/000234.php.

Homophobia, Africa and Aids. The Social Affairs Unit. http://www.socialaf fairsunit.org.uk/blog/archives/000137.php.

L'affaire Behzti. The Social Affairs Unit. http://www.socialaffairsunit.org.uk/ blog/archives/000770.php.

Lesbian jokes: A reply to Janet Bing's reply. Humor 17(3). 329-330. DOI: https://doi.org/10.1515/humr.2004.016.

Lesbian jokes: Some methodological problems. A reply to Janet Bing and Dana Heller. Humor 17(3). 311-321. DOI: https://doi.org/10.1515/humr.2004.014. 
Leslie Illingworth at the Political Cartoon Gallery. The Social Affairs Unit. http://www.socialaffairsunit.org.uk/blog/archives/000185.php.

Masterpieces from the Ny Carlsberg Glyptotek at the Royal Academy. The Social Affairs Unit. http://www.socialaffairsunit.org.uk/blog/archives/000179. php.

Review of Eric Richards, Britannia's children, Emigration from England, Scotland, Wales and Ireland since 1600. Albion: A Quarterly Journal Concerned with British Studies 36(4). 704-705.

Review of Graeme Ritchie, The linguistic analysis of jokes. Journal of Literary Semantics 33(2). 189-197. DOI: https://doi.org/10.1515/jlse.2004.33.2.196.

The right to joke. London: Social Affairs Unit. http://socialaffairsunit.org.uk/ digipub/content/view/11/27/.

The strange death of moral Britain. New Brunswick, N.J.: Transaction Publishers.

Three Centuries of Women Travellers at the National Portrait Gallery. The Social Affairs Unit, 13 October. http://www.socialaffairsunit.org.uk/blog/ archives/000184.php.

Victor Raskin on jokes. Humor 17(4). 373-380. DOI: https://doi.org/10.1515/ humr.2004.17.4.373.

Why I ... . Times Higher Education Supplement (1662). 16.

Why should children have to learn science? The Social Affairs Unit. http://www.socialaffairsunit.org.uk/blog/archives/000166.php.

You can't say that: the growing threat to civil liberties from anti-discrimination laws. Economic Affairs 24(3). 79-80.

\section{5}

Do the Irish look like monkeys? asks Christie Davies after seeing Conquering England - Ireland in Victorian London at the National Portrait Gallery. The Social Affairs Unit. http://www.socialaffairsunit.org.uk/blog/archives/ 000414.php.

European ethnic scripts and the translation and switching of jokes. Humor 18(2). 147-160. DOI: https://doi.org/10.1515/humr.2005.18.2.147.

Jokes and groups. London: Institute for Cultural Research.

The lies of feminism, the lies of Mexican identity - a personal view of Frida Kahlo at Tate Modern. The Social Affairs Unit. http://www.socialaffairsunit.org. uk/blog/archives/000505.php. 
On Retirement: escaping from bureaucratic socialism - and getting on with writing that might actually interest people. The Social Affairs Unit. http://www. socialaffairsunit.org.uk/blog/archives/000573.php.

Recalls the bulldog spirit of caricaturing. Times Higher Education Supplement (1692). 15-15.

Review of Benjamin Constant, Principles of politics applicable to all governments. The Independent Review 9(4). 598-601.

Review of Deepak Lal, In praise of empires: Globalization and order. Economic Affairs 25(4). 85. DOI: https://doi.org/10.1111/j.1468-0270.2005. 00603a.x.

Review of James D. Bloom, Gravity fails: the comic Jewish shaping of modern America. Humor 18(1). 116-117.

Review of John D. Morgan and Pittu Laungani, Eds., Death and bereavement around the world, volume 3: Death and bereavement in Europe. Mortality 10(2). 165-166. DOI: https://doi.org/10.1080/13576270500102864.

Review of Philip H. J. Davies, MI6 and the machinery of spying, structure and process in Britain's secret intelligence. Political Studies Review 3(3). 410-411. DOI: https://doi.org/10.1111/j.1478-9299.2005.00030_2.x.

Review of Wolfgang K. Hünig, British and German cartoons as weapons in World War I. Humor 18(3). 340-344.

The rise and fall of the first globalisation. Economic Affairs 25(3). 55-57. DOI: doi:10.1111/j.1468-0270.2005.00573.x.

Searching for jokes: Language, translation, and the cross-cultural comparison of humour. In Toby Garfitt, Edith McMorran \& Jane Taylor (eds.), Anatomy of laughter, 70-85. London: Legenda.

Sir Edward Heath, raglafart. The Social Affairs Unit. http://www.socialaffair sunit.org.uk/blog/archives/000520.php.

Stalin's favourite cartoonist Boris Efimov at the Political Cartoon Gallery. The Social Affairs Unit. http://www.socialaffairsunit.org.uk/blog/archives/000680. php.

Time to laugh at the Icons of the gay community at Getty Images Gallery. The Social Affairs Unit. http://www.socialaffairsunit.org.uk/blog/archives/000530. php.

Understanding anti-Americanism: Its origins and impact at home and abroad. Economic Affairs 25(3). 81-82.

Why the 2012 Olympic Games should go to London not Paris. The Social Affairs Unit. http://www.socialaffairsunit.org.uk/blog/archives/000477.php. 


\section{6}

Come back Don Quixote, we need you. The Social Affairs Unit. http://www. socialaffairsunit.org.uk/blog/archives/001290.php.

Comic Welsh English in Shakespeare. Humor 19(2). 189-200. DOI: https:// doi.org/10.1515/HUMOR.2006.010.

Dewi the dragon. Talybont, Ceredigion: Y Lolfa Cyf.

Did cowards flinch? A cartoon history of the Labour Party 1906-2006 at the Political Cartoon Gallery. The Social Affairs Unit. http://www.socialaffairsunit. org.uk/blog/archives/001246.php.

Executing Saddam. The Social Affairs Unit. http://www.socialaffairsunit.org. uk/blog/archives/001253.php.

The historic failure of "me too" conservatism. The Social Affairs Unit. http://www.socialaffairsunit.org.uk/blog/archives/001003.php.

The man who hated Pooh: The Political Cartoons of E. H. Shepard at the Political Cartoon Gallery. The Social Affairs Unit. http://www.socialaffairsunit. org.uk/blog/archives/000862.php.

Review of Frank Furedi, Where have all the intellectuals gone? Confronting twenty-first century philistinism. Economic Affairs 26(2). 84-85. DOI: doi:10.1111/ j.1468-0270.2006.00641_3.x.

Review of Geoffrey K. Fry, The politics of decline: An interpretation of British politics from the 1940s to the 1970s. Political Studies Review 4(1). 76. DOI: https://doi.org/10.1111/j.1478-9299.2006.00037_2.x.

Review of Philip H. J. Davies, MI6 and the machinery of spying. Max Weber Studies 6(2). 311.

Review of Robert Gellately and Ben Kiernan, The specter of genocide, mass murder in historical perspective. Mortality 11(3). 306-308. DOI: https://doi.org/ 10.1080/13576270600774844.

Review of Tom Inglis, Truth, power and lies, Irish society and the case of the Kerry babies. British Journal of Criminology 46(3). 535-536. DOI: https://doi.org/ 10.1093/bjc/az1040.

Why does the devil have all the best posters? The Social Affairs Unit. http://www.socialaffairsunit.org.uk/blog/archives/000886.php. 


\section{7}

Age and baldness strike again: Cable and Campbell too bald and too old for politics. The Social Affairs Unit. http://www.socialaffairsunit.org.uk/blog/ archives/001639.php.

Christie Davies could not stop laughing at Borat. The Social Affairs Unit. http://www.socialaffairsunit.org.uk/blog/archives/001388.php.

Christie Davies encounters serious rubbish in Paris: Le nouveau réalisme at the Galeries nationales du Grand Palais, Paris. The Social Affairs Unit. http://www.socialaffairsunit.org.uk/blog/archives/001501.php.

Discovering chimpanzees: The remarkable world of Jane Goodall. The Social Affairs Unit. http://www.socialaffairsunit.org.uk/blog/archives/001548.php.

From hot war to Cold War: George Butterworth of the Daily Dispatch at the Political Cartoon Gallery. The Social Affairs Unit. http://www.socialaffairsunit. org.uk/blog/archives/001601.php.

From Major to minor: A satirical look at the last five Tory leaders through political cartoons at the Political Cartoon Gallery. The Social Affairs Unit. http:// www.socialaffairsunit.org.uk/blog/archives/001414.php.

Gilbert and George: Major exhibition at Tate Modern. The Social Affairs Unit. http://www.socialaffairsunit.org.uk/blog/archives/001423.php.

Humour and protest: Jokes under Communism. International Review of Social History 52. 291-305. DOI: https://doi.org/10.1017/s0020859007003252.

Nation, social class and style: a comparison of the humour of Britain and America. Stylistyka (Opole). 99-117.

Out, out, damn Scot! The Social Affairs Unit. http://www.socialaffairsunit. org.uk/blog/archives/001360.php.

Review of Brian Parsons, Committed to the cleansing flame, the development of cremation in nineteenth century England. Mortality 12(4). 386-387. DOI: https://doi.org/10.1080/13576270701609444.

Review of Diego Gambetta, ed., Making sense of suicide missions, and Anne Marie Oliver and Paul Steinburg, The road to martyr's square: A journey into the world of the suicide bomber. Mortality 12(3). 312-314. DOI: https://doi.org/10. 1080/13576270701430825.

Review of Hilary J. Grainger, Death redesigned, British crematoria: History, architecture and landscape. Mortality 12(3). 316-318. DOI: https://doi.org/10. 1080/13576270701430809.

Review of Leon Rappoport, Punchlines: the case for racial, ethnic and gender humor. Humor 20(3). 325-331. 
Review of Michael Billig, Laughter and ridicule: towards a social critique of humour. Humor 20(2). 205-212.

Review of Richard Lynn And Tatu Vanhanen, IQ and global inequality. Economic Affairs 27(3). 104-105. DOI: https://doi.org/10.1111/j.1468-0270.2007. 00769_1.x.

Review of Theodore Dalrymple, Our culture, what's left of it: The mandarins and the masses. Economic Affairs 27(2). 108-108. DOI: https://doi.org/10.1111/j. 1468-0270.2007.00747_7.x.

The Scottish schnorrocracy. The Social Affairs Unit. http://www.socialaffair sunit.org.uk/blog/archives/001566.php.

Velázquez in London. New Criterion 25(5). 53-55.

We will fight them on the beaches. The Social Affairs Unit. http://www. socialaffairsunit.org.uk/blog/archives/001377.php.

\section{8}

American jokes about lawyers. Humor 21(4). 369-386. DOI: https://doi.org/10. 1515/humr.2008.018.

Christie Davies does not know whether to scream or laugh at the EU: €urobo£ Eocks! Britain's relationship with Europe 1957-2007 at the Cartoon Museum. The Social Affairs Unit. http://www.socialaffairsunit.org.uk/blog/archives/001685.php.

Christie Davies returns to the comics of his childhood. The Social Affairs Unit. http://www.socialaffairsunit.org.uk/blog/archives/001857.php.

Gillray's heirs: Christie Davies revels in the cartoons and caricatures of Gillray and his contemporary descendants but despairs of the society that has revived him. The Social Affairs Unit. http://www.socialaffairsunit.org.uk/blog/ archives/001749.php.

In from the cold. New Criterion 27(4). 48-50.

With Paul Lewis, Giselinde Kuipers, Rod A. Martin, Elliott Oring \& Victor Raskin. The Muhammad cartoons and humor research: A collection of essays. Humor 21(1). 1-46. DOI: https://doi.org/10.1515/humor.2008.001.

Review of Edward Shils, A Fragment of a sociological autobiography: The history of my pursuit of a few ideas. Journal of Contemporary Religion 23(3). 369-370. DOI: https://doi.org/10.1080/13537900802390399.

Review of Giselinde Kuipers, Good humor, bad taste: A sociology of the joke. American Journal of Sociology 114(3). 838. DOI: https://doi.org/10.1086/597438.

Review of Marc Galanter, Lowering the bar, lawyer jokes and legal culture. Humor 21(4). 473-481. 
Review of Mike Parker, Neighbours from hell? English attitudes to the Welsh. The Social Affairs Unit. http://www.socialaffairsunit.org.uk/blog/ archives/001716.php.

Sociology and libertarianism. In Ronald Hamowy (ed.), The encyclopedia of libertarianism, 481-482. Thousand Oaks, California: Sage DOI: https://doi.org/ $10.4135 / 9781412965811$.

Three cheers for the Irish and referenda. The Social Affairs Unit. http://www. socialaffairsunit.org.uk/blog/archives/001809.php.

Undertaking the comparative study of humor. In Victor Raskin (ed.), Primer of humor research, 157-182. Berlin; New York: Mouton de Gruyter.

Walter Sickert: The Camden Town nudes. New Criterion 26(6). 49-50.

\section{9}

Art: Ireland's romanticizer. New Criterion 27(5). 47-48.

A general theory of jokes whose butts are the stupid and the canny. Acta Ethnographica Hungarica 54(1). 7-19. DOI: https://doi.org/10.1556/AEthn.54. 2009.1.2.

Humor and fear of death. In Clifton D. Bryant \& Dennis L. Peck (eds.), Encyclopedia of death and the human experience, 589-593. Thousand Oaks, California: Sage.

Humor theory and the fear of being laughed at. Humor 22(1-2). 49-62. DOI: https://doi.org/10.1515/HUMR.2009.003.

No laughing matter: Review of Jim Holt, Stop me if you've heard this: A history \& philosophy of jokes. New Criterion 27(6). 78-80. https://www.newcriterion.com/ issues/2009/2/no-laughing-matter-4023.

Post-Socialist, Socialist and never-Socialist jokes and humour: continuities and contrasts. In Arvo Krikmann \& Liisi Laineste (eds.), Permitted laughter: PostSocialist and never-Socialist humour, 17-38. Tartu, Estonia: Elm Scholarly.

Truth vs. equality. New Criterion 27(5). 19-22.

https://www.newcriterion.com/issues/2009/1/truth-vs-equality.

Wagging the slumdog. New Criterion 27(8). 31-33.

https://www.newcriterion.com/issues/2009/4/wagging-the-slumdog. 


\section{0}

A British ban on mother-in-law jokes! [letter]. Freedom First: The Liberal Magazine, 2. Mumbai: Indian Committee for Cultural Freedom. http://freedomfirst.in/uploads/ issues/pdf/521.pdf.

The comparative study of jokes. Society 47(1). 38-41. DOI: https://doi.org/10. 1007/s12115-009-9279-5.

Jokes as the truth about Soviet socialism. Folklore: Electronic Journal of Folklore 46. 9-32. http://www.folklore.ee/folklore/vol46/davies.pdf.

Parody parade: Review of The Oxford book of parodies, edited by John Gross. New Criterion 29(2). 67-69. https://www.newcriterion.com/issues/2010/ 10/parody-parade.

Review of Mark Casson, The world's first railway system: Enterprise, competition and regulation on the railway network in Victorian Britain. Economic Affairs 30(3). 99-101. DOI: https://doi.org/10.1111/j.1468-0270.2010.002037_3.x.

Review of Paul Badham, Is there a Christian case for assisted dying? Voluntary euthanasia reassessed. Journal of Contemporary Religion 25(2). 321-323. DOI: https://doi.org/10.1080/13537901003751066.

Review of Russell Heddendorf, From faith to fun: The secularisation of humour. Journal of Contemporary Religion 25(3). 501.

Review of Sharon Lockyer and Michael Pickering., eds., Beyond a joke, the limits of humour. Ethnic and Racial Studies 33(5). 901-902. DOI: https://doi.org/ 10.1080/01419871003718761.

\section{1}

Degas and the ballet: Picturing movement. New Criterion 30(3). 50-51.

Jokes and targets. Bloomington: Indiana University Press.

Logical mechanisms: A critique. Humor 24(2). 159-165. DOI: https://doi.org/ 10.1515/humr.2011.010.

Postmodernism, style \& subversion, 1970-1990. New Criterion 30(4). 54-56.

Review of John Cottingham, Why believe? Journal of Contemporary Religion 26(1). 135-137. DOI: https://doi.org/10.1080/13537903.2011.539848.

Review of S. J. D. Green, The passing of Protestant England: secularisation and social change c. 1920-1960. Journal of Contemporary Religion 26(3). 494-495. DOI: https://doi.org/10.1080/13537903.2011.616060.

The Vorticists: Manifesto for a modern world. New Criterion 30(1). 104-105. 


\section{2}

Ai Weiwei: Dropping the urn, ceramic works 5000 B.C.-A.D. 2010/The flamboyant Mr Chinnery: An English artist in India and China. New Criterion 30(6). 47-49.

The English Mother in law joke and its missing relatives. Israeli Journal of Humor Research 1(2). 12-39. http://sfilev1.f-static.com/image/users/122789/ftp/ my_files/International\%201-2/1-Christie\%20\%20Davies\%20mother\%20in\% 20law.pdf?id=11369076.

Review of Danusha V. Goska, Bieganski: The brute Polak stereotype, its role in Polish-Jewish relations and American popular culture. Ethnic and Racial Studies 35(8). 1508-1509. DOI: https://doi.org/10.1080/01419870.2012.679670.

Review of Fran de Groen and Peter Kirkpatrick, Serious frolic: essays on Australian humour. Humor 25(4). 518-520.

Review of Hans Geybels and Walter Van Herck, eds., Humour and religion: Challenges and ambiguities. Journal of Contemporary Religion 27(1). 175-176. DOI: https://doi.org/10.1080/13537903.2012.643173.

Review of John Parkin and John Phillips, Laughter and power. Humor 25(1). 108-113.

Review of Kenneth Minogue, The servile mind: How democracy erodes the moral life. Economic Affairs 32(3). 117-118. DOI: https://doi.org10.1111/j.14680270.2012.02189_2.x.

Review of Margaret Houlbrooke, Rite out of time: A study of the churching of women and its survival in the twentieth century. Journal of Contemporary Religion 27(2). 340-341. DOI: https://doi.org1010.1080/13537903.2012.675772.

Review of Simon Weaver, The rhetoric of racist humour, US, UK and global race joking. Ethnic and Racial Studies 35(6). 1096-1097. DOI: https://doi.org/10. 1080/01419870.2012.658427.

Reviews of Robert Phiddian and Haydon Manning, eds., Comic commentators: Contemporary political cartooning in Australia, and Meredith Burgmann and Yvette Andrews, The Ernies book: 1000 terrible things Australian men have said about women. Humor 25(4). 515-518.

Translating English into English in jokes and humour. In Delia Chiaro (ed.), Translation, humour and literature: Translation and humour Volume 1, 49-73. London: Continuum International Publishing Group. 


\section{3}

Becoming Picasso: Paris 1901. New Criterion 31(8). 52-53.

Facing the modern: The Portrait in Vienna 1900. New Criterion 32(4). 54-56.

Lowry and the painting of Modern life. New Criterion 32(1). 46-48.

Margaret Thatcher: Wrong on many things, but right on the one thing that mattered - or so argues Christie Davies. The Social Affairs Unit. http://www. socialaffairsunit.org.uk/blog/archives/002117.php.

Propaganda: Power and persuasion at the British Library. The New Criterion Dispatch. https://www.newcriterion.com/blogs/dispatch/propaganda-powerand-persuasion-at-the-british-library.

Review of Harvey E. Goldberg, Steven M. Cohen and Ezra Kopelowit, eds., Dynamic belonging: Contemporary Jewish collective identities. Journal of Contemporary Religion 23(1). 178-179. DOI: https://doi.org/10.1080/13537903. 2013.750869.

Review of Elliott Oring, Just folklore: analysis, interpretation, critique. Journal of the Royal Anthropological Institute 19(3). 668-669. DOI: https://doi. org/10.1111/1467-9655.12058_11.

Review of John Charles Simon, Why we laugh, a new understanding. Humor 26(1). 179-181.

Review of Polish humor and Hungarian humor. Humor, vol. 26, 389-. DOI: https://doi.org10.1515/humor-2013-0014.

Shunga: Sex and pleasure in Japanese art. New Criterion 32(3). 49-51.

\section{4}

Georgians revealed: Life, style, and the making of modern Britain/Only in England: Photographs by Tony Ray-Jones and Martin Parr. New Criterion 32(7). 43-45.

Hašek, Švejk and the Poles. Brno Studies in English 40(2). 47-66. DOI: https://doi.org/10.5817/bse2014-2-3.

In Review: Germany: Memories of a nation at the British Museum. The New Criterion Dispatch. https://www.newcriterion.com/blogs/dispatch/in-review-ger many-memories-of-a-nation-at-the-british-museum.

Kenneth Clark - Looking for civilisation. The New Criterion Dispatch. https:// www.newcriterion.com/blogs/dispatch/kenneth-clark-looking-for-civilisation.

London chronicle. New Criterion 33(4). 51-54. 
A new dawn in India. New Criterion 33(3). 26-29. https://www.newcriterion. com/issues/2014/11/a-new-dawn-in-india.

Political ridicule and humour under socialism. European Journal of Humour Research 2(3). 1-27. https://europeanjournalofhumour.org/index.php/ejhr/arti cle/view/23/pdf.

Ruin lust. New Criterion 32(9). 45-47.

Turner and the sea. New Criterion 32(8). 62-64.

\section{5}

With Bogusz Pawiński. Brud, śmierć, rozkład i gnicie: amerykańskie zaprzeczanie i brytyjskie unikanie tematu. Społeczne i kulturowe reprezentacje śmierci: koncepcje, badania i konteksty: antologia tekstów. 156-167.

Love bites. New Criterion 33(10). 55-57.

Must we blame sociology? Quadrant Magazine 59(5). 18-22.

Philosophical roughage: Review of Slavoj Zizek, Zizek's jokes: Did you hear the one about Hegel \& negation? New Criterion 33(5). 79-81.

Points of the compass II: London. Quadrant Magazine 59(10). 34-37.

Review of Jennifer Nugent Duffy, Who's your Paddy? Racial expectations and the struggle for Irish American identity. Ethnic and Racial Studies 38(8). 1440-1441. DOI: https://doi.org/10.1080/01419870.2014.973434.

Review of Josh Lambert, Unclean lips: Obscenity, Jews and American culture. Journal of Contemporary Religion 30(1). 160-161. DOI: https://doi.org/10. 1080/13537903.2015.986999.

Rubens and his legacy: Van Dyck to Cézanne. New Criterion 33(7). 43-46.

There's an old joke: Review of Mary Beard, Laughter in ancient Rome. New Criterion 34(2). 67-70.

Why same-sex marriage happened, and where we go next. Quadrant Magazine 59(7/8). 20-22.

\section{6}

Different shades of white. Freedom First: The Digital Journal of Liberal Ideas. http://www.freedomfirst.co.in/.

Goya: The portraits. New Criterion 34(5). 67-69. 
How jokes change and may be changed: Simplifying, transforming and revealing. Pótrocznik Językoznawczy Tertium. Tertium Linguistic Journal 1(1). 253-266. https://journal.tertium.edu.pl/index.php/JaK/article/view/30/23.

Letter from London. Quadrant Magazine 60(3). 20-22.

Letter from London: Immigration is theft. Quadrant Magazine 60(7/8). 32-34.

Letter from London: The great paedophile witch hunt: The wrongly accused are the real victims. Quadrant Magazine 60(10). 48-50.

Review of Jure Gantar, The evolution of Wilde's wit. Humor 29(3). DOI: https://doi.org/10.1515/humor-2016-0057.

Review of Moira Marsh, Practically joking. Humor 29(4). 635-638. DOI: https://doi.org/10.1515/humor-2016-0082.

The rise and fall of taboo comedy in the BBC. In C. Bucaria \& L. Barra (eds.), Taboo comedy: Television and controversial humour, 21-40. Cham: Springer.

Russia and the arts: The age of Tolstoy and Tchaikovsky. New Criterion 34 (9). 51-53.

Why is Wales not like Scotland? The Salisbury Review: Quarterly Magazine of Conservative Thought. http://www.salisburyreview.com/articles/governmentguidelines/.

\section{7}

Art history \& the brain. The New Criterion Dispatch. https://www.newcriterion. com/blogs/dispatch/art-history-the-brain.

Canaletto \& the art of Venice. New Criterion 36(1). 47-49.

Charisma, routinized [Review of Patricia Gherovici and Manya Steinkoler, eds., Lacan, psychoanalysis \& comedy]. New Criterion 36(2). 70-73.

The decline and fall of the French language. Quadrant Magazine 61(6). 30-32.

"Hokusai: Beyond the great wave" at the British Museum. The New Criterion Dispatch. https://www.newcriterion.com/blogs/dispatch/hokusai-beyond-thegreat-wave-at-the-british-museum.

Just a joking! Freedom First: The Digital Journal of Liberal Ideas. http://www. freedomfirst.co.in/.

Letter from London: The very model of a dodgy human rights lawyer. Quadrant Magazine 61(3). 36-38.

My first day at school. The Salisbury Review: Quarterly Magazine of Conservative Thought. http://www.salisburyreview.com/articles/first-dayschool-months-magazine/.

Karen Wilkin \& Painting after Post-Modernism. New Criterion 35(7). 41-46. 
Reply to Abedinifard. Humor 30(2). 239-246. DOI: https://doi.org/10.1515/ humor-2017-0006.

Smoke, sea \& country matters [Review of Franny Moyle, The extraordinary life \& momentous times of J.M.W. Turner]. New Criterion 35(9). 73-75.

We want our country back. The Salisbury Review: Quarterly Magazine of Conservative Thought. http://www.salisburyreview.com/articles/christie-davieswant-country-back/.

\section{8}

Judges and humour in Britain: from anecdotes to jokes. In Jessica Milner Davis (ed.), Judges, judging and humour, 41-74. Cham: Springer.

The progress of Australian humour in Britain. European Journal of Humour Research 5(4). 15-28. DOI: https://doi.org/10.7592/EJHR2017.5.4.davies.

Review of Matthew Baigell, The implacable urge to defame, cartoon Jews in the American press, 1877-1935. Humor 31(1). 163-165. DOI: https://doi.org/10. 1515/humor-2017-0104.

The strange castes of British India. Freedom First Digital. http://www.free domfirst.co.in/.

\section{Bionote}

\section{Moira Marsh}

Moira Marsh is a folklorist and humor scholar, with a focus on vernacular humor and humor theory. She is the author of Practically Joking (2015) and numerous articles with an emphasis on the reception of humor in social settings. Moira has served on the Executive Board of the International Society for Humor Studies and as the coordinating book review editor for Humor: International Journal of Humor Research. Email: molsmith@indiana.edu 